\title{
Hodgkin's disease and pericardial effusion
}

\author{
J. P IL CHER a nd M. ZU B A I R \\ Sheffield Cardio-Thoracic Unit, Northern General Hospital, Sheffield S5 7 AU
}

A case of Hodgkin's disease presenting with pericardial effusion is described. The relevant literature is reviewed.

Murchison (1870) first described Hodgkin's disease involving the heart and pericardium. Such involvement is uncommon and occurs in only 3 to $10 \%$ of cases at necropsy (Jackson and Parker, 1947; Jakob and Zirkin, 1960). Clinical evidence of involvement of the heart or pericardium is even less common and is almost always a late or terminal event in an already diagnosed disease. Pericarditis as the only presenting manifestation of Hodgkin's disease is extremely rare and we have not found a case reported previously in this country.

\section{CASE REPORT}

A 19-year-old male apprentice pattern maker presented with a six weeks' history of chest pain and shortness of breath. There had been a weight loss of $15 \mathrm{~kg}$. during this time. He had previously been in good health, and a mass miniature chest radiograph taken at work some six months previously had been considered normal. A further full-size film taken three weeks after the onset of the illness showed cardiac enlargement suggestive of congenital heart disease.

On examination he looked pale, but there was no lymphadenopathy and no abnormal signs outside the

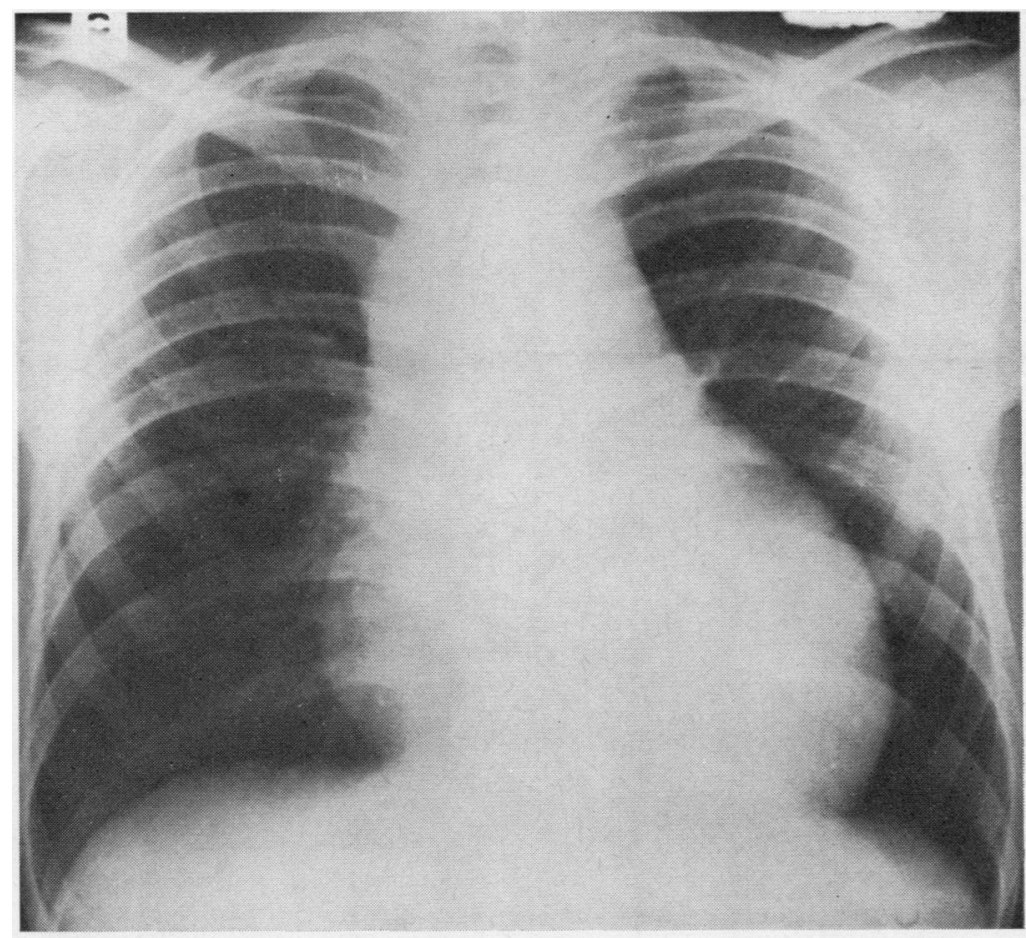

FIG. 1. Chest radiograph shows globular cardiomegaly and upper mediastinal widening. 
cardiovascular system. The area of cardiac dullness was increased with soft heart sounds: the blood pressure was normal at $140 / 80 \mathrm{~mm}$. Hg. The chest film (Fig. 1) and electrocardiogram (Fig. 2) show features suggestive of pericarditis with some additional upper mediastinal widening on the radiograph.

Further investigations in hospital showed a lowgrade pyrexia accompanied by a normocytic anaemia with a persistent polymorphonuclear leucocytosis but without eosinophilia. The leucocyte alkaline phosphatase score was high. The erythrocyte sedimentation rate was grossly elevated but with normal serum proteins, blood urea, and liver function tests. The Mantoux test was negative to $1 / 10,000$ and tests for past viral infections, rheumatic fever, disseminated

1

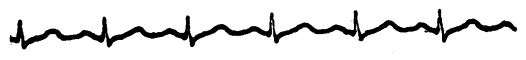

II

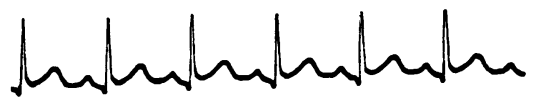

III

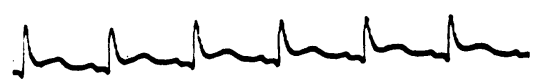

lupus erythematosus, rheumatoid arthritis, and toxoplasmosis were all negative. Bone marrow examination and cervical node biopsy both showed nonspecific changes. Pericardial aspiration revealed 400 ml. of uniformly blood-stained fluid which was sterile and in which no abnormal cells were seen.

Following pericardial aspiration repeat chest radiographs showed persistent superior mediastinal widening suggestive of glandular enlargement. This was confirmed by tomography which demonstrated an anterior lobulated mass without compression of the trachea or major bronchi. During the course of these investigations, he complained of hoarseness of voice and appeared to be developing early signs of superior venal caval obstruction. Treatment was started with

\section{AVR}

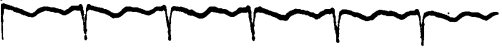

AVL
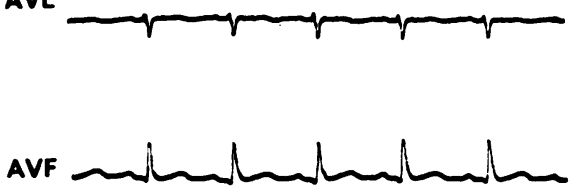
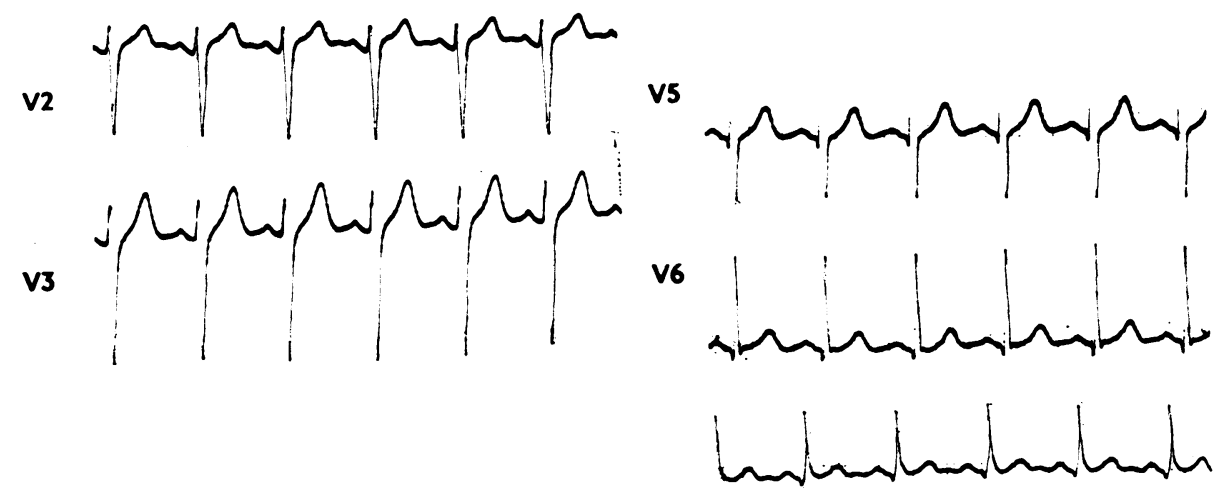

FIG. 2. ECG shows ST elevation SII and SIII. 
prednisolone, vincristine, mustine, and procarbazine. Following this there was initially a striking clinical improvement with weight gain, general well-being, and loss of pyrexia. The haemoglobin rose and the chest radiographs showed a shrinkage in the mediastinal adenopathy accompanied by remission of the hoarseness of voice and of the clinical signs of venous obstruction. However, the leucocyte alkaline phosphatase score remained high, and some seven weeks after the start of treatment he again complained of hoarseness of voice and increasing shortness of breath with further clinical evidence of superior vena caval obstruction. These symptoms rapidly progressed so thoracotomy was undertaken in an attempt to relieve respiratory obstruction. Cardiac arrest occurred duing induction of the anaesthetic and resuscitative measures were not successful.

At necropsy there was a large nodular mass surrounding the ascending aorta and pulmonary artery, adherent to and compressing the trachea and right main bronchus. There was a small multiloculated effusion in the pericardium which was not invaded by tumour, and although the heart itself was normal, the superior vena cava was almost completely obstructed. Histology of this mass revealed the typical appearances of Hodgkin's disease. The cervical lymph nodes, liver, and spleen were free of tumour.

\section{COMMENT}

There appear to be only two reports in the English literature in which Hodgkin's disease presented solely as a pericarditis (Hagans, 1950; Bastai and Nazzi, 1953). In the former report an episode of chest pain preceded the appearance of cervical adenopathy by some months, though there was no proof that this pain was due to the pericardial involvement. Eight other cases have been reported in the foreign literature (Ayerza and Cernich, 1943 ; Appiani, 1956 ; Pernot, Schoumacher, Pernot, and Masse, 1957; Dughera, Meda, and Nazzi, 1958-2 cases; Mariot, 1960; Brun, Freycon, and Froment, 1964-2 cases). In the majority of these, as in the case reported here, mediastinal adenopathy was suspected before pericardial aspiration on account of upper mediastinal widening or irregularity of the cardiac contour in the chest radiograph. In all, it became more apparent after aspiration. In 4 of these 10 reported cases the pericardial effusion was accompanied by pleural effusion. This assisted the diagnosis in one patient in whom undifferentiated malignant cells were found in the pleural fluid. Pericardial aspiration did not reveal malignant cells in any of the four patients in whom it was performed but did so in one other in whom pericardial effusion was a prominent feature (Mérab, Taleb, Saliby, Eliane, Naffah, and Kyriakos, 1959).
This pericarditis is almost always non-specific and only very rarely caused by actual pericardial invasion. Nevertheless, the volume of fluid contained within the pericardial cavity is said to be sufficient sometimes to cause a rise in venous pressure and hepatomegaly (Brun et al., 1964). Actual constrictive pericarditis with invasion of the pericardium has been reported once (Duane and Rottino, 1967). Their patient received radiotherapy to the mediastinum, but the time interval between treatment and the onset of constriction was only five months. A rise in jugular venous pressure in our patient occurred after pericardial aspiration and was due to superior vena caval compression. This is not rare and has been reported previously (Ritvo, 1940). Presentation of the disease with pericardial effusion without later extension outside the thoracic cavity does not seem to have been recorded previously. We think that although Hodgkin's disease is a rare cause of pericardial effusion, it should be considered in the differential diagnosis even without other clinical signs of the disease. Elevation of jugular venous pressure may be caused by the volume of contained pericardial fluid, or rarely by actual constriction, or as in our patient by superior vena caval compression.

\section{REFERENCES}

Appiani, L. (1956). La polisierosite come sintomo iniziale del granuloma maligno. Tumori, 42, 371.

Ayerza, L and Cernich, R. (1943). Granuloma maligno primitivo del pericardio (caso princeps). Rev. Asoc. méd. argent., 57, 981

Bastai, P., and Nazzi, V. (1953). Morbo di Hodgkin a localizzazione primitivamente pericardica. Atti Soc. ital. Cardiol., 15, vol. 2 p. 35 .

Brun, F., Freycon, F., and Froment, R. (1964). Deux observations de maladie d'Hodgkin à forme de péricardite liquidienne initiale. Lyon méd., $211,811$.

Duane, R. J. and Rottino, A. (1967). Constrictive pericarditis caused by Hodgkin's disease. N.Y. St. J. Med., 67, 288.

Dughera, L., Meda, A., and Nazzi, V. (1958). La pericardite, quale segno precoce di localizzazione mediastinica nelle affezion neoplastiche sistemiche del tessuto linforeticolare. Minerva med. (Parte sci.), 49, 4201.

Hagans, J. A. (1950). Hodgkin's granuloma with pericardial effusion. Amer. Heart J., 40, 624.

Jackson, H., and Parker, F. (1947). Hodgkin's Disease and Allied Disorders. Oxford Úniversity Press, New York.

Jakob, H. G., and Zirkin, R. M. (1960). Hodgkin's disease with involvement of the heart and pericardium. J. Amer. med. Ass., 173, 338.

Mariot, A. (1960). Contribution à l'étude des tumeurs primitives du péricarde. Thèse, Lyon, No. 236.

Mérab, A., Taleb, N., Saliby, E., Eliane, E., Naffah, M. J., and Kyriakos, S. (1959). Les péricardites hodgkiniennes. A propos d'un cas kos, S. (1959). Les péricardites hodgkiniennes. A propos d'un cas de maladie de Hodgkin révélée par une péricardite avec épanchement et présence de cellules de Sternt
ponction. Sem. Hôp. Paris, 35, 2590.

Murchison, C. (1870). Case of 'lymphadenoma' of the lymphatic system, spleen, liver, lungs, heart, diaphragm, dura mater, etc. Trans. path. Soc. Lond., 21, 372.

Pernot, C., Schoumacher, P., Pernot, M., and Masse, P. (1957) Péricardite chronique hodgkinienne à grand épanchement. Action favorable de l'ypérite nitrée par voie intrapéricardique. Presse méd., 65, 2193.

Ritvo, M. (1940). Hodgkin's disease. Report of a case with unusual longevity and invasion of the heart and pericardium. New Engl. J. Med., 223, 891. 